\title{
Kaskelottens sidste drøm
}

- og andre europæiske billeder

\author{
PATRICK MAC MANUS
}

\section{Spøgelser}

Fra lavlandet ser vi mod ét magisk bjerg. Dér ligger sanitoriet, hvor vi blev syge i det tyvende århundrede. En duft af småkage og erindring hænger stadig i lokalet. I et andet rum taler en blind mand om prisen på lammenyrer i D. Byen er måske borte nu, opslugt af siv i et uformeligt delta. En forpint kontorfunktionær tegner labyrintiske korridorer i forlængst sammenstyrtede ministerier.

\section{Bræen}

I gletscheren fandt de liget af en mand, der vogtede dyr på skråningen for titusind år siden. Han hår og hans negle var blevet klipper få dage inden hans død. Der var sirlige tegn på hans ryg og arme. Som alle andre har han blot kaldt sit land for menneskenes land.

Han vidste ikke, at der ville komme en dag, hvor en gud i skikkelse af en tyr ville bortføre en pige og trænge ind i hende. Han vidste ikke, at den panikslagne ville give navn til landet. Han vidste ikke at panikken ville forfølge dem alle, han vidste ikke at de vanskabte ville skjule sig ved at omskabe alt omkring sig.

\section{Mantra i Venedig}

På lodrette aksler drejer tusind bedemøller på bjergenes skråning. Med hver drejning gentages bønnens formel af vinden. 
På flag og vimpler flakser bønnens urolige skrift i kløften mellem himmel og jord.

Princippet i den tibetanske bedemølle blev skitseret af den italienske ingeniør Mariano Jacopo Taccola i sit skrift De machinis fra årene omkring 1438-1450. Den lå til grund for en række turbiner, der blev udviklet af hans samtidige.

I de århundreder blev tusinder af centralasiatiske slaver holdt i de italienske byer. Kirkelige forordninger satte sig imod handel med kristne. Til gengæld lå de islamiske lande for tæt på de italienske kyster, med stor risiko for at slaver derfra ville kunne flygte. Slaver fra de buddhistiske områder var en løsning. De blev købt af handelsmænd fra Genoa ved havnene i Sortehavet, oftest i en alder på mellem elleve og femogtyve år. De bragte kendskabet til bønnens teknologi med sig.

Bedemøllernes bøn var til Avalokitesvara. Avalokitesvara er bodisattva, den oplyste. Den, der ser. Den, der hører alle verdens lyde. Den, der redder de nødstedte. Den, der våger over alle skabninger og hører deres gråd. Avalokitesvara lever i det rene land, i landet med lotus.

I blafrende sejl og faner i en venetiansk havn hører Avalokitesvaras børn en bøn. I roterende turbiner, drevet af en fremmed vind, kan de se bønnens forgæves bevægelse mellem himmel og jord.

\section{Hispaniola}

Med forstenet ansigt ser han skibene på horisonten. Han har set dem før i sine drømme. I solen løber de unge mænd, kvinderne og børnene ned mod stranden. I sine drømme har han set dem løbe ned i en mørk skakt, hvorfra de ikke vil vende tilbage.

Efter fyrre dage er skibene sluppet gennem kalmebæltet, der skiller verdener. Et kvælende og livsløst bælte, hvor havet er tungt som bly og himlen uden sol. Sejl hænger som ligklæder og mandskaber bliver vanvittige. I sin tid blev dette bælte skabt af et him- 
melsk væsen, hvis tid nu er omme. Skabt som en mystisk barriere.

Skellet mellem verdener er nu brudt. Hundrede år senere var der på øen kun to hundrede tilbage af et folkeslag på over hundredetusind. Antropologen skriver, at det mindre var på grund af sygdom og mishandling end af målløs rædsel over det nye, der hjemsøgte dem.

\section{Knuderne}

Det var alt, hvad han havde at give hende. Hans tid var forbi og hans liv, den sidste finske troldmand. Han gav hende et reb med tre knuder. Med syngende stemme fortalte han om knuderne. I hver af knuderne var der en vind, den ene stærkere end den anden. Den tredje var som en orkan. Hun skulle spare på dem og kun løsne dem, når det var nødvendigt.

Den nat i september 1911 døde han. Tre dage senere forlod hun skoven og vendte tilbage til skolen i Tampere. Efter endt skolegang blev hun ansat i skattevæsenet, på fjerde kontor. Hun blev gift med en bygningsingeniør og fik to børn. De blev skilt efter treogtyve år og hun flyttede ind $\mathrm{i}$ et hus med elevator. Børnene så hun næsten aldrig. En dag blev hun fundet død i vaskekælderen.

Allerede længe forinden var hendes hænder blevet for svage til at løsne knuderne, ikke mindst den tredje af dem.

\section{Rav}

Stormen fra nordvest havde varet hele natten og var nu stilnet af. Med sin stok løftede han i tangen. Ravet lå i sandet. Han var på vej over til hende og den sommer bar hun det om sin hals i en sølvkæde.

I andre tider blev det brugt som røgelse. Mod himlen steg en duft af harpiks fra gyldne skove, som kun guder har betrådt. 
Tre år senere omkom hun. Ravet blev ikke brændt. Sammen med andre smykker blev det samlet på en presenning. Bjerge af sko og paraplyer og briller var der også.

Fra lejren steg lugten af et brændoffer, sort og kvalmende som det tyvende århundrede.

\section{Wittgensteins blokhus}

Stjernen slukkes nu i den iskolde by. Og engang i stjernens tegn blev sneen rød af messianisk vold. Men verden er alt for stor til en simpel drøm. Verden er alt for lille til en simpel drøm.

Det var måske også det, han ville sige, blandt meget andet. Mystikeren og matematikeren i et blokhus ved en sø langt ind i Sognefjorden. I sin knappe stil noterer han på en papirlap, at himmel og helvede skal menneskene ikke lege på jorden. Det er forbeholdt gud, det er forbeholdt det, hvorom der intet kan siges. Og derfor kan vi blot tale om det, der kan tales om. Og gøre det, der kan gøres. Det er begrænset, og det er alt.

Tavst drejer himlen om sig selv og viser tegn på tegn. Vi tyder dem i evigt skift fra en skrøbelig jord.

\section{Passage}

Han prøvede at dø i det tyvende århundrede. På et kors i Manilla, i en kreaturvogn i Bielefeld, af sult i Afmadu, i en flygtningestrøm i Sulaymaniyah, af kvælning i Steensraat og igen i Halabja, i en celle i Diyabakir, i en underjordisk gang i Quang Tri, i ildstormen i Dresden, i en massaker i Ayacucho, af udmattelse i Srebenica, i et fortærende lys på Kyushu, i fred i Ballyvoile, hvor kalven drikker af floden. Denne død fandt han ikke, men sin egen.

Han døde i en måneløs nat i Port-Bou. Det var en god nat at krydse grænsen i, og bringe sig i sikkerhed. Men han opgav. Som så meget andet opgav han også denne flugt. Han var mester i det ufuldførte, det ufærdige. Bag sig i mange byer, som snart ville 
blive mål for natlige angreb, efterlod han spredte papirer, notater og udkast. Og var på denne måde et billede på tiden og den kommende ruin.

\section{Drift}

Gradvist bevæger vi os bort i kontinenternes glidning fra hinanden. I denne næsten umærkbare bevægelse findes alle andre. Her findes alle afsked og alle længsler, alle midlertidige tilnærmelser og alle tab. De forrevne former giver vi navn, og ethvert navn er samtidig en forkastelse.

Jeg er forbitret over udslettelserne og undergangene, over døende formers forgæves udkast, over uprøvede modellers endeligt, over alle fravalg og fortrængte alternativer og alle irreversible tab. For det er sandsynligt, at der her havde været en mulighed for andre muligheder.

\section{$X$. De samtidige}

Hans navn var Frédéric Mistral. Mistral som den kolde og tørre storm fra nord. Kold og tør farer den fra højlandet gennem Rhônedalens snævre tragt. Frédéric er den mest kendte af den gruppe provencalske digtere, som ville skabe ligeværdighed mellem landsdelens sprog og det franske rigssprog.

Ethvert 'rigssprog' er centralismens dialekt. I kolde skolelokaler sidder børnene i gennemblødt tøj og terper sprogets officielle standarder. I skolegården taler de endnu deres egen latterlige mundart. Og i sin aforistiske stil skriver den tyske Friedrich til gengæld, at det er 'skolens fornuft, der har gjort Europa til Europa'.

Forvitrende og ubønhørlig er tiden og vinden. Tagene og ejendele løftes og spredes, falder til jorden og splintres. Trøstesløst vandrer Frédéric gennem dalen og stormen. Og sindsformørket blev Friedrich fundet i Torino, hvor han i gråd omfavnede en mishandlet hest. 


\section{Den henfaldende geografi}

Vi går igennem et landskab, som mister sine navne og alle sine betydninger.

Vi har glemt borgerkrigene og forræderierne. Vi har glemt bjergene og skovene, som vi søgte tilflugt i. I Helsinki rasler sporvognen over en bro, som vi kæmpede om i fem dage og fem nætter. Forskrækket finder børnene gamle geværer i sneen.

Tilbage er kroppen, som rystes af konfuse oprør. Kroppens sprog er det sidste sprog. Med stumme tegn peger den på sig selv i en opblussen af urolige eksemer.

\section{Fiktionen}

Der er intet Europa. I et fremspring af et vældigt asiatisk kontinent blev en fiktion til virkelighed og en virkelighed til fiktion. Begge dele har mærket verden.

Men ikke før vi selv blev mærket af det. Det var her, den store $ø$ velse fandt sted. Her blev indøvet de fortrængninger og afgrænsninger, der sidenhen blev overført til verden. Her skete der en forfinelse af metoderne, af straffene, af voldsformer, af akkumulationsformer, af ekspropriationerne, af fordommene, af argumentationen og af logikken. Når virkeligheden ikke er logisk, skal dens præmisser etableres med magt, og historien nærmer sig tautologiens form. Og heraf følger alle skridt og alle slutninger, ledsaget af triumfens koraler.

Kun ved helt at undslippe termerne kan der siges noget andet. For der er andre sange her og i verden.

\section{Marts}

Istanbul i denne årstid er tusinder af magre og frysende mænd, der bærer byrder gennem vrimlende gader. En polstret saddel over nakken fordeler vægten. Foroverbøjet går de gennem larmen, med-sænkede hoveder gennem mængden. 
Byen er en ung mand med øjne fulde af tårer. Han er skibsværftsarbejder i Bremen. Der mangler et stempel i hans papirer for at han kan vende tilbage. I fem dage har han vandret mellem kontorer. Nu sidder han i ølstuen, hvor en rå blæst trækker gennem det nøgne lokale.

Det er det, jeg ser og skriver ned. Også her skriver jeg med venstre hånd, den urene hånd, nødtørftens hånd, ekskrementets hånd.

\section{Historiens hjerte}

Historien er skrevet ind i hans ansigt. I hans blik, hans næsebor og mund. Den lille historie, der ligger under den store. Det er ikke summen af små historier, der udgør den store. Den store historie er en abstraktion, og ikke en sum.

Ingen tæller og lægger sammen. Kun den enkelte, som ofte selv er blevet stum. Til den store historie er der de store ord, til den lille er ordene få og små.

Der vil hverken være dansende lam, der glædes en dag, eller stinkende bukke, der fordrives fra lyset. En gammel polsk mand sætter sig i lokalet på Benedykta Hertza og bestiller en CocaCola.

\section{Mediterrænsk liv}

Her er vinterens mørke og skovens, og et andet mørke. Det hviler over dette land, og over hendes sind. Midt i sit periodiske vanvid skreg hun på Kungsgatan : slipper jeg aldrig ud af barnekammeret. Her blev de spøgelser skabt, der sidenhen hjemsøgte hende livet igennem. Og ikke hende alene, men alle andre overlevende fra et barnemord uden ende.

I denne skygge opstod drømmen om Middelhavet, drømmen om et mediterrænsk liv. Et solfyldt liv midt på jorden, hvor fortid og nutid smelter sammen i en lysende helhed. Fortiden er forvandlet til en lysende ruin, rædselen er fortrængt af den strålende form. 
De drog derhen til lyset, pilgrimme fra vuggens mørke, pilgrimme fra mørkets vugge. I dag fragtes millioner til et forgiftet hav, som endnu stråler af dette lys.

\section{Gibraltar}

Vi lever i modløse byer og har glemt kamelernes udholdenhed. Vi har glemt, at vi har glemt det. Et sted i verden skriver Ibn Khaldun i sin bog om civilisationens faser, historien om ørkenen og byen, om de nøjsomme og de grådige, om de hårdføre og de lade. Eller forklædt som tallerkenvasker er han allerede her, eller måske kun på vej, gemt i lasten på et skib, der fragter ham over det smalle stræde mellem kontinenterne.

Han iagttager, han ser. Han ser banen, han ser gentagelsen, som alligevel aldrig er den samme. Han smiler som en dreng, mørk og sky, og er ældre end os allesammen. Han smiler i dampen fra hotelkøkkenet.

\section{Belejring}

Det er den eneste vej ud af byen i de tusind dage. Et mudret hul fører ned i en snæver tunnel under en raseret lufthavn. Efter ottehundrede meter på alle fire står han i en ussel landsby, som stadig er under regeringstroppernes kontrol. Og tilbage igen, slæbende på en sæk slimet mel fra en velgørenhedsorganisation.

Det er ikke her, han vil være. I bogkasserne, som de havde flyttet fra hovedbiblioteket efter de første brande, fandt han et eksemplar af Almagestum Novum. Skrevet i 1651 af munken Giovanni Riccioli. Munken var den, der navngav de mørke pletter på månen som havområder. Mare Imbrium. Mare Nectaris. Mare Serenitatis. Mare Tranquilitatis. Bygernes hav, nektarens hav, det fredfyldte hav, det rolige hav. Og navnene blev stående siden.

Han ligger på sin ryg i en lille båd og ser op på jorden langt borte. Og i sin hånd holder han en line med en krog af sølv til månefisken. 


\section{Tilgivelsen}

I rækker sidder de på kirkebænkene i Dundalk og venter. Fra skriftestolens mørke aflukke kan han høre en mumlen og en gentagelse.

Hans krop blev lettere. De eftermiddage løb han i gaderne og gennem skoven, som var der dengang. Han faldt ikke over stenene. I de timer bevægede han sig med en atmosfærisk lethed, ubesværet som på et andet himmellegeme.

I skyggen af denne verden vokser andre verdener frem. Stumme verdener og uoprettelige universer, en tavshed af uigenkaldelige former. Tilgivelse er knyttet til livets evne til at regenerere sig selv. Til skabelsens evne til at genskabe sig selv. I takt med at denne evne mindskes eller udslettes helt, mister tilgivelse sin mening. Den falder ud af verden, ud af sproget.

$\mathrm{Nu}$ løber han ikke mere i lette spring. Den moderne synd kan ikke rummes af noget ritual.

\section{Den sidste krig}

I stridsvogne, med standarter, trommer og skingre horn, i geled efter geled drager de ud gennem byens port. Våbnene er som en skov af stejle træer, jorden skælver under deres trin.

En vedvarende storm udtørrede alle cisterner, og hele deres land var uden vand. Så holdt de råd og efter fælles beslutning drog de i krig mod vinden. Da de kom ud i ørkenen, blæste vinden op og begravede dem i sand. Det er Herodot, der skriver om det i Historiens IV Bog, et folks sidste krig.

Den sidste krig vil altid være mod jorden. Og sådan går vi ind i mørket. Bag os efterlader vi en forgiftet by, en jord, hvor intet gror. Men midt i stormens øje, hvor alt er stille, er der et øjeblik, hvor alt vil stå klart. Et øjeblik af forsinket indsigt. Og på den måde kan vi alligevel dø lykkelige. 


\section{Mærket}

Jeg er fanget $i$ en fortid, mærket af en overgang. Fra jorden og havet til gaden og byen, fra et sprog til et andet, fra et navn til et andet. Mit navn var blødt og varmt, nu er det hårdt og kantet. Andre har lettere ved at være $i$ tiden. For dem, er den den tid, der er.

Erfaring er indgroet som en smertende negl. Og jeg halter gennem en verden, som er skabt for at den kan opløses igen. En verden, hvor erindring er en elektronisk billedforstyrrelse, der beklages af en ulastelig speaker.

I en dansk forstad står en bus i krydset mellem Tempovej og Turbinevej, postnummer 2750. Her er jeg og vil sidde i en tjæret båd - ved Helvick, en sort og skarp form i en fjord, som fik sit navn af mændene i de lange skibe.

\section{Kaskelottens sidste drøm}

Jeg er fanget $i$ dette stræde. Fortumlet vrider og vender jeg kroppen og har mistet vejen til dybet. Forvildet slår jeg omkring mig, gispende på revlen, fanget i det lave vand. På afstand er halen som et sort og arret sejl.

Men det er måske helt anderledes. Det er måske noget andet, der sker. Det er måske en tilblivelse. Jeg vender måske tilbage til et fastland, jeg engang forlod. Med nyvoksne ben og arme og en ny stemme vender jeg tilbage. Fra Grimstad kommer de mig imøde, hujende børn på cykler og kvinder med flagrende hår.

Og halefinnen vil ligge endnu på stranden med indtørrede tegn. 